\title{
The Levites and Idolatry: A Scribal Debate in Ezekiel 44 and Chronicles
}

\section{Introduction}

The stratification within the Levitical priesthood, namely the distinction between the priests and the non-priestly, second-tier Levites in the Jerusalem temple, has been at the core of the reconstructed history of the religion of ancient Israel. According to the classical scheme constructed by Julius Wellhausen, which has thus far been the most influential theory, this stratification originated from the Josianic reform between especially the Jerusalemite priests and the priests from local sanctuaries (2 Kgs 23:9). Alternative explanations have been suggested by scholars such as Kurt Möhlrenbrink, Antonius H. J. Gunneweg, and Frank M. Cross especially in favor of a pre- and early-monarchic dating of the division. ${ }^{1}$ Nevertheless, both Wellhausenian and alternative views share the basic notion that the Josianic reform was a critical juncture for the internal division within the Levitical group. However, a more recent tendency, especially in Europe, has dated the relevant biblical texts to the Persian period, therefore dating both the formation of the Levitical priesthood and its internal stratification to that period as well. ${ }^{2}$

\footnotetext{
1 Kurt Möhlenbrink, “Die levitischen Überlieferungen des Alten Testaments,” ZAW 52 (1934): 184-231; Antonius H. J. Gunneweg, Leviten und Priester: Hauptlinien der Traditionsbildung und Geschichte des Israelitisch-Jüdischen Kultpersonals, FRLANT 89 (Göttingen: Vandenhoeck \& Ruprecht, 1965); Frank Moore Cross, Canaanite Myth and Hebrew Epic (Cambridge, MA: Harvard University Press, 1973). For a more comprehensive review of scholarship, see, Jaeyoung Jeon, “Levites, I. Hebrew Bible/Old Testament," in EBR 16 (2018), 337-346. Especially, for a sharp contrast on this issue between North-American and European scholarship, see, Peter Altmann, "What Do the 'Levites in Your Gates' Have To Do with the 'Levitical Priests'?: An Attempt at European-North American Dialogue on the Levites in the Deuteronomic Law Corpus," in Levites and Priests in Biblical History and Tradition, ed. Mark A. Leuchter and Jeremy M. Hutton, AIL 9 (Atlanta, Ga.: SBL Press, 2012), 135-54.

2 See, e.g., Nadav Na'aman, "Sojourners and Levites in the Kingdom of Judah,” ZAR 14 (2008): 237-79, at 261-72; Daniel E. Fleming, The Legacy of Israel in Judah's Bible: History, Politics and the Reinscribing of Tradition (Cambridge: Cambridge University Press, 2012), 72-90; Jean-Daniel Macchi, Israël et ses tribus selon Genèse 49, OBO 171 (Göttingen: Vandenhoek \& Ruprecht, 1999); Harald Samuel, Von Priestern zum Patriarchen: Levi und die Leviten im Alten Testament, BZAW 448 (Berlin: De Gruyter, 2014). See further, Jeon, “Levites” with references.
}

Jaeyoung Jeon, University of Lausanne 
Whatever its historical origin may have been, it is during the Persian period that the more intensified struggles for, and probably against, the stratification were documented. The priestly scribal efforts to codify and perpetuate the distinction between the Aaronite and/or Zadokite priests and the rest of the Levites are visible in the late-Priestly or post-Priestly texts in Numbers, such as chapters 3-4, 8, and 16-18 as well as Ezekiel 44. The latter in particular provides an alternative origin of the stratification, being the Levites' service in idol worship vis-à-vis the Zadokites' loyalty to Yhwh. This is a humiliation and the harshest criticism of the non-Zadokite Levites

In Chronicles, however, the Levites' possible connection to a previous idol worship is totally eliminated, suggesting a conscious and deliberate muting effort by the Chronicler. Could this have been a Levites's scribal response to the priestly polemics against the Levites? Based on the scholarly consensus that Chronicles represents Levitical interests or was written by a Levitical scribe, I seek to investigate here the contradictory attitude toward the Levites' connection to idol worship in Ezekiel 44 and Chronicles. I then prove that the Chronicler acknowledged the Zadokite accusation against the Levites and responded to it through a reshaping of a history of the Levites as always piously faithful to Yhwh worship in Jerusalem. Since this scribal response was subtle and implicit, it would be helpful to employ relevant theoretical frameworks in order to present it clearly. The argument in the last part of the essay will suggest that the social theories of Pierre Bourdieu and social memory can enhance our understanding of the implicit intertextuality.

\section{The Accusation of Idol Worship Against the Levites}

\subsection{The Lateness of the Zadokite Redaction}

The accusation against the Levites appears in Ezekiel within a section that regulates the clerical order of the future temple (Ezek 44:6-31). In this section, Yhwh denounces the people for defiling the temple by allowing foreigners to enter the sanctuary and especially assigning to them duties of the temple (vv. 7-8). Yhwh's solution for this prior situation is to separate the temple space by different degrees of holiness and assign control of the spaces to a hierarchy of two clerical groups. The preeminent group, the sons of Zadok as the Levitical priests, shall be exclusively responsible for the altar service in the sanctuary (משמרת מקדש, vv. 15-16); the secondary group, the remainder of the Levites, shall not be permitted to access 
to the sanctuary (v. 13) but instead assigned duties outside the sanctuary such as gatekeeping, temple service (משרת הבית), and slaughtering sacrificial animals for the people (vv. 11, 14).

The accusation against the Levites appears as the rationale for this distinction. Here, the Levites have been deprived of their priesthood because of their participation in the people's previous idol worship (v. 10); they even served the people in the presence of the idols, and thus Yhwh swore to prohibit them from accessing the sanctuary and serving as priests (v. 12-13). Yet, the Zadokites kept charge of the sanctuary when Israel went astray from Yhwh (v. 15). The priesthood of the new temple thus exclusively remains among them (vv. 15-16).

The classical Wellhausenian view of the history of ancient Israelite religion dates the present passage to the exilic period, attributing it either to Ezekiel himself or to his disciples and regarding it as an important link between the priestly hierarchy from the Josianic reform (2 Kgs 23:5-9; Deut 18:7) and the perpetuated class-division between the Aaronite priests and the Levites in $\mathrm{P}^{3}$ However, since Hartmut Gese's redaction-critical study of Ezekiel $40-48,{ }^{4}$ the present passage has been regarded as one of the youngest layers or additions in Ezekiel 40-48, which is itself a series of late expansions of Ezekiel's prophecy. Gese identified three independent sources/layers, defining the passages mentioning the privilege of the Zadokites (Ezek 40:46c; 44:6-16, 28-30a; 45:13-15) as the youngest “Zadokite layer” (Sadoqidenschicht). Walther Zimmerli developed this independent source model into a model of multiple stages of reworking (Fortschreibung) and attributed the passages to an early post-exilic expansion with further verses (e.g., Ezek 45*; 46:19-24; 48:30-35). ${ }^{5}$ Gunneweg narrowed the scope of the Zadokite passages by assigning mainly Ezekiel 44:6-31 to the "Zadokite section," rather than a literary layer, with other small additions. ${ }^{6}$ Some later studies have suggested models with two or three layers in Ezekiel 40-48, still attributing the Zadokite passages to a younger (sometimes the youngest) layer dating to the

3 See further, Jeon, “Levites." See, also, e. g., George A. Cooke, A Critical and Exegetical Commentary on the Book of Ezekiel, ICC (Edinburgh: T. \& T. Clark, 1936), 480-83; Walther Eichrodt, Ezekiel: A Commentary, OTL (London: SCM Press, 1970), 560-66; Walther J. Zimmerli, Ezekiel: A Commentary on the Book of the Prophet Ezekiel 2: Chapters 25-48, trans. by James D. Martin, Hermeneia (Philadelphia: Fortress Press, 1983), 447-59.

4 Hartmut Gese, Der Verfassungsentwurf des Ezechiel (Kap. 40-48): Traditionsgeschichtlich Untersucht, Beiträge Zur Historischen Theologie 25 (Tübingen: J.C.B. Mohr, 1957).

5 See Gese, Verfassungsentwurf, 31-33, 108-23; Zimmerli, Ezekiel 2, 447-59.

6 Gunneweg, Leviten und Priester, 188-203. 
Persian period. ${ }^{7}$ Although the models are complex, our passages are thought to be very late additions dated to the fifth and fourth centuries BCE. ${ }^{8}$

The unity of the present section of Ezekiel 44:6-16 is doubted by some of these scholars, mainly because the issue of idol worship in vv. 9-16 shows no direct relationship to the presence of the foreigners in the temple (vv. 6-8). Thilo A. Rudnig, for instance, separates Ezekiel 44:6-8 and vv. 9-16 and claims that the former belongs to an earlier layer containing an original accusation against the exiles, while the latter develops the former as the distinction in the priestly class. ${ }^{9}$ Nathan MacDonald further argues that the reproach of the foreigners in vv. $6-7^{\star}$, 9 was originally followed by the commissioning of the Levitical priests (vv. 15*). For him, the distinction between the Zadokite priests and Levites is altogether a late addition. ${ }^{10}$ The entire passage of vv. 6-16, however, forms a structured and coherent literary unit. As shown above, Yhwh reproaches the presence of the foreigners in the sanctuary and their temple duties in vv. 6-8 and sets a two-fold protection for the sanctity of the future temple by the priests and Levites (vv. 9-16). The issue of idol worship by the Levites is mentioned as the rationale for the division between the Zadokites and Levites, which is a logical premise of the two-fold protection. This issue needs not to be directly connected to the problem of the foreigners.

It is neither necessary nor my purpose to evaluate the different compositional models for Ezekiel 40-48 in this essay; the relative lateness of those Zadokite passages (Ezek 40:46c; 44:6-16, 28-30a; 45:13-15) in their literary context seems obvious. For instance, the distinction between those responsible for the temple duties (שמרי משמרת הבית) and those serving at the altar (שמרי משמרת המזבח) is presented already in Ezekiel 40:45-46. They are all priests, however, and there

7 Vogt, for example, assumes three stages of literary expansion in Ezekiel 40-48 and assigns Ezek 44-46 to the second phase. Tuell suggests only a single phase of expansion - including the Zadokite passages - conducted during the reign of Darius (522-486). Konkel reconstructs two stages of expansion, assigning our passages to the second stage, after 515 BCE. See Ernst Vogt, Untersuchungen zum Buch Ezechiel, Analecta Biblica 95 (Rome: Biblical Institute Press, 1981), 127-75; Steven S. Tuell, The Law of the Temple in Ezekiel 40-48, HSM 49 (Atlanta: Scholars Press, 1992), 75-77; Michael Konkel, Architektonik des Heiligen: Studien zur Zweiten Tempelvision Ezechiel (Ez 40-48), BBB 129 (Berlin / Wien: Philo, 2001), 240-43.

8 For example, Rudnig reconstructs thirteen redactional insertions. He separates Ezekiel 44:6-7* and Ezekiel 44:6-16* and dates them to the fifth and fourth centuries, respectively. See Thilo A. Rudnig, Heilig und Profan: Redaktionskritische Studien zu Ez 40-48, BZAW 287 (Berlin: De Gruyter, 2000), 224-330.

9 Rudnig, Heilig und Profan, 205-7. This position is followed by Samuel, Von Priestern, 367-68. 10 Nathan MacDonald, Priestly Rule, Polemic and Biblical Interpretation in Ezekiel 44 (Berlin, Boston: Walter de Gruyter, 2015), 51-55. 
is no hierarchy between them. Only a relative clause attached at the end (v. 46b) defines the altar priests as sons of Zadok who are privileged over other Levites. However, the mention of the sons of Zadok is rather alien to its literary context, and this half-verse is usually regarded as a late addition. ${ }^{11}$ If we remove v. $46 \mathrm{~b}$, the present passage (vv. 45-46a) knows neither the distinction between the Zadokite priests and the Levites nor the guilt of the Levites. The Zadokite redaction developed the earlier division of the priests according to their functions into the hierarchal system of Zadokites and Levites. In addition to Ezekiel 44:46b, two other passages mentioning the Zadokites (Ezek 43:19a*; 48:11) were also inserted later to the existing texts. In Ezekiel 43:19, the lengthy description of the "seed of Zadok" has been inserted between פר בן בקר and ונתתה אל הכהנים, producing an awkward gap between the two closely related clauses. The following verses simply designate the priests as הכהנים (vv. 24, 27). Ezekiel 48:11 recapitulates the division between the Zadokites and Levites with the language of Ezekiel 44:9-16 and has been attached redundantly to v. 10. The latter already has לכהנים as the beneficiary of the sacred portion of the land and is a complete sentence by itself, while the attached v. 11 only complicates the syntax. These three Zadokite additions presuppose texts in different sections of Ezekiel 40-48, which strongly indicates the lateness of the Zadokite redaction.

The lateness of the Zadokite redaction, especially in Ezekiel 44, is also confirmed by its intertextual connections with other biblical passages usually dated to the Persian period. For example, our passage is often viewed in a polemical relationship with Isaiah 56 (Trito-Isaiah) that allows gentiles to enter the sanctuary. ${ }^{12}$ Also, the division of duties between the Zadokite priests and the Levites shows a close literary affinity to Numbers (16-)18, regarded as one of the youngest parts of the Priestly text. ${ }^{13}$ The Zadokite passages are often thought to be influ-

11 See, e.g., Gese, Verfassungsentwurf, 21-22; Gunneweg, Leviten und Priester, 188 Zimmerli, Ezekiel 2, 368.

12 See, e. g., Michael Fishbane, Biblical Interpretation in Ancient Israel (Oxford: Clarendon Press, 1985), 138-143; Joachim Schaper, "Rereading the Law: Inner-Biblical Exegesis of Divine Oracles in Ezekiel 44 and Isaiah 56," in Recht und Ethik im Alten Testament: Beiträge des Symposiums "Das Alte Testament und die Kultur der Moderne" anlässlich des 100. Geburtstag Gerhard von Rad (1901-1971), Heidelberg, 18-21 Oktober 2001, eds. Bernard M. Levinson and Eckart Otto (Altes Testament und Moderne 13. Münster: Lit, 2004), 125-44. And see the references there. See also, Steven S. Tuell, “The Priesthood of the 'Foreigner': Evidence of Competing Politics in Ezekiel 44:1-14 and Isaiah 56:1-8," in Constituting the Community: Studies on the Polity of Ancient Israel, eds. John T. Strong and Steven Shawn Tuell (Winona Lake, IN; Eisenbrauns, 2005), 183-204; MacDonald, Priestly Rule, 26-33.

13 See, e. g., Gese, Verfassungsentwurf, 64-65; Gunneweg, Leviten und Priester, 198-203; Raymond Abba, "Priests and Levites in Ezekiel," VT 28 (1978): 1-9; Fishbane, Biblical Interpretation, 
enced by Numbers 18 or attributed to the same hand. ${ }^{14}$ All of these redactional and intertextual studies indicate the lateness of the Zadokite redaction.

\subsection{The Guilt of the Levites}

\subsubsection{A Historical or Literary Reference?}

According to the Wellhausenian view, the guilt of the Levites mentioned in Ezekiel 44:10, 12 stems from their service at the local sanctuaries before the Josianic reform. This view is still attractive for those who agree with the classical scheme of ancient Israelite religion, especially about the priest/Levite division. ${ }^{15}$ Nevertheless, the Levites' guilt is described in very general terms - the worship of idols (גילולים) without specifying any historical context. Further, the recent late dating of the passage to the mid- or even late Persian period creates a chronological gap between the Josianic reform and the present passage. Scholars have thus suggested alternative explanations, mainly by finding reference to the passages in the canonical history. ${ }^{16}$ Some have identified it in the Hexateuchal stories: for example, the rebel-

138-143; Rodney K. Duke, "Punishment or Restoration? Another Look at the Levites of Ezekiel 44,6-16,” JSOT 40 (1988): 61-81, here 64-75; Stephen L. Cook, “Innerbiblical Interpretation in Ezekiel 44 and the History of Israel's Priesthood”, JBL 114 (1995): 193-208; Daniel I. Block, The Book of Ezekiel. 2 vols., NICOT (Grand Rapids: Eerdmans, 1997), 628-29; Rudnig, Heilig, 295-304; Konkel, Architektonik, 311-13; MacDonald, Priestly Rule, 41-47.

14 While most of the scholars mentioned in n 13 regard that Ezekiel 44 is dependent on Numbers 18, Cook assigns them to the same hand. See, Cook, "Innerbiblical Interpretation."

15 See, e. g., Keith W. Carley, The Book of the Prophet Ezekiel, Cambridge Bible Commentary (Cambridge: Cambridge University Press, 1974), 294; Nigel Allan, “The Identity of the Jerusalem Priesthood during the Exile”, HeyJ 23 (1982): 259-269, esp. 265-269; Aelred Cody, Ezekiel: With an Excursus on Old Testament Priesthood, Old Testament Message 11 (Wilmington, DE: Michael Glazier, 1984), 159-160; Joachim Schaper, Priester und Leviten im achamenidischen Juda: Studien zur Kult- und Sozialgeschichte Israels in Persischer Zeit, FAT 31 (Tübingen: Mohr Siebeck, 2000), 79-95.

16 See, e. g., Jon D. Levenson, Theology of the Program of Restoration of Ezekiel 40-48, HSM 10 (Missoula: Scholars Press, 1976), 134-140; Raymond Abba, “Priests and Levites in Ezekiel," VT 28 (1978): 1-9; Menahem Haran, Temples and Temple-Service in Ancient Israel: An Inquiry into the Character of Cult Phenomena and the Historical Setting of the Priestly School (Oxford: Clarendon Press, 1978), 104-111; Gordon J. McConville, "Priests and Levites in Ezekiel: A Crux in the Interpretation of Israel's History,” TynB 34 (1983): 3-32; Duke, "Punishment or Restoration?” 66-72; Tuell, Law of the Temple, 150-151; Iain M. Duguid, Ezekiel and the Leaders of Israel (VTSup 56. Leiden; New York: E.J. Brill, 1994), 79-80; Cook, “Innerbiblical Interpretation,” 193-208; Joseph Blenkinsopp, "The Judaean Priesthood during the Neo-Babylonian and Achaemenid Periods: A Hypothetical Reconstruction,” CBQ 60 (1998): 25-43, here 41-42; Rudnig, Heilig und Profan, 
lion of Korah (Num 16-18), ${ }^{17}$ idol worship of Baal Peor (Num 25), ${ }^{18}$ and the story of the Gibeonites (Josh 9). ${ }^{19}$ Others suggest that our passage refers to idol worship during the monarchic period, such as Jeroboam's golden calves ${ }^{20}$ and the idolatry under Manasseh's reign, ${ }^{21}$ or to foreigner involvement, such as the Carites (2 Kgs 11:4-8) and the temple servants (נתינים) from Solomon's reign (Ezra 2:43-54). ${ }^{23}$

Whereas these different views, whether classical or alternative, endeavor to identify a certain (or multiple) historical or literary event(s) behind the guilt of the Levites, skepticism about such attempts has also been expressed, in line with the growing recognition of the passage's late nature. ${ }^{24}$ This skepticism has led some scholars to focus on the literary context of the book of Ezekiel and to find literary connections between Ezekiel 1-39 and the present passage. Steven Tuell, for example, argues that the idols (גלולים) in Ezekiel 44 refer to those in Ezekiel 6:3-6; 8:10; 14:3-4; $;^{25}$ Alice Hunt regards Ezekiel 44 as midrash upon Ezekiel 23; ${ }^{26}$ MacDonald suggests that Ezekiel 44:10-14 is an inner-biblical interpretation of Numbers 18 and Ezekiel 14; ${ }^{27}$ Benjamin Kilchör claims similarly that the present passage refers via Ezekiel 14:1-11 to Ezekiel 8, in addition to Numbers $18 .{ }^{28}$ For our purpose, those views emphasizing the intertextuality within the Book of Ezekiel has primary relevance.

291-295; Konkel, Architektonik des Heiligen, 304-317. See further Benjamin Kilchör, “The Meaning of Ezekiel 44,6-14 in Light of Ezekiel 1-39,” Biblica 98 (2017): 191-207, here 192-93.

17 See Cook, "Innerbiblical Interpretation."

18 Levenson argues that the present Zadokite stratum combines an old Aaronite polemic against the Mushites (e.g., Num 25 and 1 Kgs 31-32) with the newer polemic against all of the priests of the shrines; see Levenson, Program of Restoration, 136-39.

19 Zimmerli, Ezekiel 2, 455.

20 Abba, "Priests," 5; Levenson, Program of Restoration, 136. See also criticism of this view by Levenson, Program of Restoration, 134-35.

21 Harran, Temples, 106.

22 Leslie C. Allen, Ezekiel 20-48, WBC 29 (Dallas: Word Books, 1990), 261; Jacob Milgrom, "Ezekiel and the Levites," in Sacred History, Sacred Literature: Essays on Ancient Israel, the Bible, and Religion in Honor of R.E. Friedman on his Sixtieth Birthday, ed. Swana Dolansky (Eisenbrauns: Winona Lake, IN, 2008), 3-12.

23 Zimmerli, Ezechiel 2, 1125. For further summary of the different views, see Kilchör, "Meaning," 192-93.

24 See, e. g., Eichrodt, Ezekiel, 565; McConville, “Priests and Levites,” 25-26; Rudnig, Heilig, 295; Konkel, Architektonik, 317.

25 See Tuell, Law of the Temple, 149.

26 See Alice Hunt, Missing Priests. The Zadokites in Tradition and History, LHBOTS 452 (New York: T\&T Clark, 2006), 141-42.

27 See MacDonald, Priestly Rule, 41-51.

28 See Kilchör, “Meaning,” 204-5. 


\subsubsection{Understandings of the Levites's Guilt by the Audiences/Readers of Yehud}

The scholarly views introduced thus far have generally been author-oriented approaches concerned mainly with what the author/redactor meant by the "guilt" of the Levites. The focus of this essay is, nevertheless, how the passage was understood by the audiences/readers of Persian Yehud, particularly by the Levitical scribal circle including the Chronicler and also by their expected audiences/ readers. Although we have a very limited knowledge of how much and among whom the Ezekiel scrolls were preserved, circulated, read, and recited during the period, reasonable inferences should still be possible. When the present Zadokite redaction was completed, it was included as an integral part of a scroll of Ezekiel's prophecy. Once the additions were included in the scroll and the latter was accepted by the religious community, all of the prophetic discourses in the scroll, including the additions, would have been regarded as the prophet's own words. The redactor's scribal work gained the authority of the prophet Ezekiel in this way. This was presumably the purpose of the ancient redactors for choosing to add their own words to existing authoritative texts rather than write their own texts.

When the Zadokite passages were added to a scroll of Ezekiel ${ }^{29}$ and this version was accepted by the community as authoritative, those passages including that of Ezekiel 44 would have naturally been understood as a continuation of the preceding prophecy of Ezekiel himself. In this context, the worship of idols and the guilt of the Levites in our passage should have been understood by the audiences/ readers based on what they had heard/read previously from the scroll; namely, our passage was primarily understood in the context of the Book of Ezekiel.

As mentioned above, scholars have discussed our passage's intra-textual connections to other Ezekiel passages mentioning idol worship, especially Ezekiel $6 ; 8 ; 14 ; 23 .^{30}$ Although their arguments concern the redactors' literary activity, the literary connections (including verbal correspondences) should also have influenced the audiences/readers to understand the Levites' guilt in line with the blame of the Israelites' idolatry in the previous parts of Ezekiel. ${ }^{31}$ These judgement speeches of Ezekiel are delivered mainly to the inhabitants of Jerusalem and Judah from the waning decades of the Judean monarchy. Their worship of idols

29 Here I would prefer to use the term "a scroll of Ezekiel” in order to include the earlier stages of the text during its expansion before the present form of the book of Ezekiel.

30 It has been broadly recognized that the description of the sins of the past in Ezekiel 44:6-15 was written with formulaic language and phraseology deeply rooted in the judgement speeches of Ezekiel 1-24; see, e. g., Zimmerli, Ezekiel 2, 456; Levenson, Program of Restoration, 134.

31 For instance, the term גלולים is a expression for idols that is typical to Ezekiel, occurring approximately 35 times in Ezekiel among 45 occurrences in the Hebrew Bible. 
(גלולים) thus stems mostly from this period, except for several verses in Ezekiel $20 .{ }^{32}$ The idolatry in which the Levites participated was most likely understood by contemporary audiences/readers as that of the late monarchic period.

Understandings of the present passage was possibly broader among the literate elites, especially the scribal circles, depending on the range of their knowledge of other authoritative texts. The Chronicler, the focus of the second part of this essay, constructed his view of the history of Israel primarily based on the Deuteronomistic history, especially Samuel and Kings, though he exhibits a familiarity with some Pentateuchal and prophetic texts. ${ }^{33}$ It is thus most likely that the Chronicler understood the Levites' guilt in Ezekiel 44 through background knowledge of his primary source. The Books of Kings also employ the term גלולים for describing idols throughout the monarchic period: the idols made before the reign of Asa (1 Kgs 15:12), Ahab's idols (1 Kgs 21:26), Manasseh’s idolatry (2 Kgs 21:11), the idols eliminated by Josiah's reform (2 Kgs 23:24), etc. In the literary context of Kings, a general description of idolatry such as Ezekiel 44:10-12 can be understood not only for the later period of the Southern kingdom but also as for the Northern and Southern Kingdoms throughout the entirety of their existences. This was presumably the way in which the Chronicler, whose major source is Kings, understood the idolatry in Ezekiel 44. Should this be the case, it would be interesting to examine how the Chronicler, who strongly advocates for Levitical interests, responded to the Zadokite accusation of the Levites's participation of idolatry. Yet before this examination, I would like to clarify two questions as its logical premises: (1) Did the Chronicler know the Book of Ezekiel? (2) Was it necessary to respond to the accusation in Ezekiel 44? The following sections address these two questions.

\section{Ezekiel and Chronicles}

The questions of the Chronicler's knowledge of the prophetic literature and its acceptance as an authoritative source has long been discussed. ${ }^{34}$ Scholars com-

32 Ezekiel 20:7-8 blames the exodus generation for worshiping the idols of Egypt, whereas vv. 16, 24 speak of the idolatry during the wilderness period.

33 For further discussions, see Ehud Ben Zvi, "Who Knew What? The Construction of the Monarchic Past in Chronicles and Implications for the Intellectual Setting of Chronicles," in Judah and the Judeans in the Neo-Babylonian Period, ed. Oded Lipschitz (Winona Lake, IN: Eisenbrauns, 2003), 349-60. See also the references below in $n 34$.

34 Gerhard von Rad, "The Levitical Sermon in I and II Chronicles," in The Problem of the Hexateuch and Other Essays (London: SCM, 1984), 267-80 (first published in German as "Die levi- 
monly recognize the Chronicler's knowledge through explicit mentions of prophets or prophetic books, such as Jeremiah, Isaiah, and Zechariah, or quotations therefrom. ${ }^{35}$ The mention of prophetic texts as well as some other biblical texts mentioned only in Chronicles attest to their recognition and use by the Chronicler as authoritative sources. ${ }^{36}$ Hugh G. M. Williamson further maintains that "the use he makes of them in his work shows that within his community they had already been accepted as authoritative religious texts." ${ }^{37}$ Ezekiel must have been among the prophets who attained preeminent authority in the community of Yehud, considering its profound (mutual) influence on the formation of the different layers of the Priestly texts in the Pentateuch. Interestingly, however, the Chronicler never mentions the prophet Ezekiel, nor has Chronicles scholarship regarded Ezekiel as one of the Chronicler's authoritative sources, ${ }^{38}$ so that the possible relationship between the two texts has generally been neglected.

For an ancient author knowing a certain text versus making explicit literary reference to it belong to two different realms of cognitive activity. Ancient scribes could react to other texts in various ways, not only by accepting concepts and language but also by negating, manipulating, polemicizing, or intentionally ignoring them. The Chronicler was not an exception. Given the various avenues available for scribal reaction, there are a few clues that imply the Chronicler's knowledge of Ezekiel. Firstly, the Chronicler's mention of Nebuchadnezzar making Zedekiah swear an oath by God (2 Chr 36:13) may refer to the same notion in Ezekiel 17:11-17, 19. ${ }^{39}$ Japhet sees in this parallel the Chronicler drawing on the depiction in Ezekiel

tische Predigt in den Büchern der Chronik," in Festschrift für Otto Procksch [Leipzig: Deichert and Hinrichs, 1934], 113-24); Sara Japhet, The Ideology of the Book of Chronicles and Its Place in Biblical Thought, 2nd ed., BEATAJ 9 (Frankfurt am Main: Peter Lang, 1997), 183; Louis Jonker, "The Chronicler and the Prophets. Who Were His Authoritative Sources?” SJOT 22 (2008): 275-95; Ben Zvi, “Who Knew What?”; Ben Zvi, “One Size Does Not Fit All: Observations on the Different Ways That Chronicles Dealt with the Authoritative Literature of Its Time," in What Was Authoritative for Chronicles?, ed. Ehud Ben Zvi and Diana V. Edelman (Winona Lake, IN: Eisenbrauns, 2011), 13-35; Steven J. Schweitzer, "Judging a Book by Its Citations: Sources and Authority in Chronicles," in What Was Authoritative for Chronicles? ed. Ehud Ben Zvi and Diana V. Edelman (Winona Lake, IN: Eisenbrauns, 2011), 37-65.

35 See further the elaborate list of quotations or allusions of biblical texts in Steven Schweitzer, "Judging a Book by Its Citations".

36 See, e. g., Jonker, “The Chronicler and the Prophets”; Ben Zvi, “Who Knew What?”

37 See Hugh G. M. Williamson, Studies in Persian Period History and Historiography, FAT 38 (Tübingen: Mohr Siebeck, 2004), 243.

38 For example, even Schweitzer's elaborate list of intertextual connections (“Judging a Book by Its Citations") does not include Ezekiel.

39 See, e.g., Ralph W. Klein, 2 Chronicles: A Commentary, Hermeneia (Minneapolis, MN: Fortress Press, 2012), 539; Raymond B. Dillard, 2 Chronicles, WBC 15 (Waco: Word Books, 1987), 300; 
but using different terminology. ${ }^{40}$ While this case as a reference to Ezekiel is up for debate, what is directly relevant to the current discussion are the possible references in Chronicles to the Zadokite passages in Ezekiel, in particular those about the Levites.

Gary N. Knoppers made a thorough comparison between the Levitical duties described in 1 Chronicles 23:28-32 and the relevant passages in $\mathrm{P}$ and Ezekiel. ${ }^{41}$ Although the literary affinity between 1 Chronicles 23:28-32 and P has already been acknowledged by scholars, ${ }^{42}$ the former's relationship with Ezekiel has been either ignored ${ }^{43}$ or deliberately denied. ${ }^{44}$ Rodney Duke, for example, claims that "what the Chronicler recorded is not inconsistent with $\mathrm{P}$ and does not extend as far as the regulations of Ezekiel." ${ }^{45}$ Nevertheless, Knoppers presents concrete examples of the Chronicler's knowledge not only of P but also of Ezekiel, including the Zadokite passages. For example, the terms describing the Levitical duties in 1 Chronicles 23:28-32 are unique to $\mathrm{P}$ and Ezekiel: choice flour for the cereal offering סלת (ל)מנחה (1 Chr 23:29; Num 15:4, 6; 28:5, 9, etc.; Ezek 46:14) and the griddle מחבת (v. 29, Lev 2:5; 6:14; 7:9; Ezek 4:3). ${ }^{46}$ There are also close parallels among the three texts, according to Knoppers, in terms of Levitical assignments, such as the work for the Temple of God in general (v. 28;

Christopher Begg, "The Non-Mention of Ezekiel in the Deuteronomistic History, the Book of Jeremiah and the Chronistic History," in Ezekiel and His Book: Textual and Literary Criticism and Their Interrelation, ed. Johan Lust, Bibliotheca Ephemeridum Theologicarum Lovaniensium 74 (Leuven: University Press, 1986), 340-343: 342. Begg claims that the report of defiling temple in $2 \mathrm{Chr}$ 36:14 also presupposes Ezekiel 8.

40 Japhet, Chronicles, 1070.

41 See Gary N. Knoppers, "Hierodules, Priests, or Janitors? The Levites in Chronicles and the History of the Israelite Priesthood.” JBL 118 (1999): 49-72. Some scholars regard the Chronicles passage as a secondary addition; see, e. g., Wilhelm Rudolph, Chronikbücher, HAT 21 (Tübingen: J.C.B. Mohr, 1955), 155-156; Hugh G. M. Williamson, “The Origins of the Twenty-Four Priestly Courses,” in Studies in the Historical Books of the Old Testament, ed. John A. Emerton, Studies in the Historical Books of the Old Testament, VTS 30 (Leiden: Brill, 1979), 251-68: 258. However, Sarah Japhet and others have effectively proven that the passage is interconnected in its concepts and language with other parts of Chronicles and thus an integral part of the book; see Japhet, Chronicles, 421; Knoppers, “Hierodules, Priests, or Janitors,” 71; Peter B. Dirksen, 1 Chronicles, Historical Commentary on the Old Testament (Leuven: Peeters, 2005), 281; Jonker, 1 \& 2 Chronicles, 151.

42 See, e. g., Japhet, Chronicles, 418-421; Dirksen, 1 Chronicles, 281; Louis C. Jonker, 1 \& 2 Chronicles, 151.

43 See above $n 34$.

44 For denials of the relationship, see, e.g., Roddy Braun, 1 Chronicles, WBC 14 (Waco: Word Books, 1986), 235; Duke, “The Levites of Ezekiel,” 78-79 n 30.

45 Duke, “The Levites of Ezekiel,” 79.

46 See Knoppers, “Hierodules, Priests, or Janitors," 55-57. 
Ezek 44:14), and the watch over the tent of meeting/house sanctuary of Yhwh (v. 32, Num 18:3; 31:30, etc.; Ezek 44:14). ${ }^{47}$ These examples are certainly not decisive evidence of the Chronicler's knowledge of Ezekiel, since it is not impossible that $\mathrm{P}$ was a common source for both Ezekiel and Chronicles. However, some parts of the Chronicles passage are closer to Ezekiel than P. For example, the expression עבדת בית ה' (v. 32) is quite similar to that of the

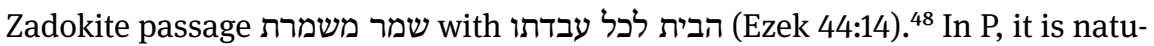
עבדת המשכן (Num 8:24; 18:6, etc.) עבדת אהל מועד (Num 3:7, 8); the Chronicler's phrase (v. 32) rather awkwardly mentions both משדת and משרת אהל מועד (8:24; ביה ה' probably the former from P and the latter from Ezekiel.

A more intriguing observation by Knoppers concerns the way the Chronicler responds to the Priestly and Ezekiel texts. He observes that the Levites are responsible for the choice flour for the cereal offering, which are unleavened wafers (1 Chr 23:29), while P (Num 6:1-21; 15:1; 28:1-31) and Ezekiel (46:11-14) do not mention the Levites; maintaining a balance in measuring capacity and length is a Levitical duty (1 Chr 23:29), while it is the duty of the whole people in P (Lev 19:3536) or the prince (נשיא) in Ezekiel (45:9-12); the watch over the sanctuary (משרת) הקדש is assigned exclusively to the priests (Num 18:4-5, cf. Num 3:28), which is defended in Ezekiel 44, while all Levites are responsible for this task in Chronicles (1 Chr 23:25-26). ${ }^{49}$ Knoppers then concludes:

The Chronicler draws on Priestly terminology, but he does so to expand Levitical responsibilities and to blur some of the clear distinctions advanced by the Priestly writers and defended by Ezekiel..$^{50}$

The Chronicler did not simply repeat $\mathrm{P}$ and Ezekiel regulations about the Levites and priests, but instead creatively modified and revised their presentations to promote Levitical status. This is a good example of the strict hierarchical division between priests and the Levites in $\mathrm{P}$ and Ezekiel being blurred and reputed in favor of the Levites in Chronicles. If the Chronicler not only knew the Zadokite passages in Ezekiel 44 but also modified them to counter the negative perception of the Levites, one may have a safer ground to inquire how the Chronicler

47 Ibid., 59-62. See also, Klein, 1 Chronicles, 455.

48 The עבדה in v. 32 may apparently be read as the work of only the sons of Aaron. Yet, when it is read together with other relevant passages (1 Chr 6:33; 23:24, 28 etc.), עבדה here includes Levitical work as well.

49 See Knoppers, "Hierodules, Priests, or Janitors," 62-64, and further examples therein. 50 Ibid., 64. 
responded to the Zadokite accusation of Levitical participation in idol worship (Ezek 44:10-12).

\section{The Levites and Idolatry in Chronicles}

We saw above that the accusation of idol worship against the Levites (Ezek 44:1012) was made in very general terms, so that it is hardly connected to a specific historical event. Nevertheless, for the contemporary audiences/readers receiving the book of Ezekiel as a whole, the idolatry in question would have pointed primarily to the time of the late Judean monarchy. Furthermore, literate elites like the Chronicler who were familiar with the written history of the monarchy, such as from the Books of Kings, could have understood the sinful past broadly, as the entire monarchic period. It is thus necessary to examine the Chronicler's accounts of the major historical events connected to idolatry in order to find responses to this accusation. Among many, the accounts of Jeroboam's golden calves and Josiah's reform may constitute two exemplary cases. Before the analysis of the two accounts, however, a closer look into a notable aspect of the Chronicler's terminology of idols would be helpful for further discussion.

\subsection{No Idols (גלולים) in Chronicles}

In the Zadokite redaction, the Levites are blamed for their involvement in the people's worship of idols (גלולים, Ezek 44:10-12). The term for idols, גלולים, is used most frequently in Ezekiel, yet the Chronicler was admittedly familiar with it through legal texts (Lev 26:30; Deut 29:16) and his major source, Kings (1 Kgs 15:12; 21:26; 2 Kgs 17:12; 21:11; 21:21; 23:24). Among the six verses in Kings, three have parallels in Chronicles (1 Kgs 15:12; 2 Kgs 21:21; 23:24). Interestingly, however, the Chronicler modifies the verses by replacing גלולים with other terms. Further, he never uses the term גלולים in his entire writing. The three other passages in Kings are omitted in Chronicles due to the latter's lack of interest or a theological revision; ${ }^{51}$ the omission of גלולים in Chronicles seems to be neither accidental nor coincidental, but rather deliberate, if we assess the parallels in detail:

511 Kgs 21:26 mentions גלולים in describing Ahab's idolatry; the Chronicler is not interested in Ahab and mentions him only in relation to Judah (e. g., 2 Chr 18; 21:6; 22:3, etc.). In the Chronicler's description of Ahab, however, his idolatry is mentioned very generally as adultery (ה.נ.t, 2 Chr 21:13) or evil (הרע, 22:4), without the term גלולים. Similarly, the historical summary of the sins 
(1) Asa's Reform (1 Kgs 15:12): According to the brief report of Asa's reform (vv. 11-13), he removed all the idols (כל הגלולים) his ancestors had made (v. 12). This verse references the time of Solomon, Rehoboam, and Abijam, implying that these Judean kings made גלולים. This is an important verse that summarizes the idolatry in Judah in the early period of the divided monarchy and its parallel is found in 2 Chronicles 14:3 that also describes Asa's religious reform. The report of the reform seems unexpected in its literary context, since in Chronicles, Rehoboam is humbled before Yhwh and Abijam is also described positively. This verse is thus almost certainly from 1 Kgs 15:12.52 The Chronicler, however, alters the account of reform by adding more details, such as foreign altars, high places, pillars, and sacred poles, but omits גלולים. As Japhet has observed, this alteration is "neither incidental nor merely stylistic," 53 considering the Chronicler's repetition of the verses preceding and following 1 Kings 15:12 without much modification (1 Kgs 15:11a, 13 // 2 Chr 14:2; 15:16). ${ }^{54}$

(2) Amon's Idolatry (2 Kgs 21:21): The verse describing Amon's idolatry is paralleled in 2 Chronicles 33:22. The Kings passage says that Amon served (ויעבד) and worshiped (וישתחו) "the idols (הגלולים)” that his father had served. The Chronicler rephrases this so that Amon served (זיעבדם) and sacrificed (זבחלם) to "the idols (הפסילים)" that his father had made. The basic meanings of the two verses are identical; the term for "idols" is modified from גלים to גלולים

(3) Josiah's Reform (2 Kgs 23:24): The Chronicler's account of the purge of the idolatrous objects ( $2 \mathrm{Chr} 34: 3-7$ ), though brief, parallels the account in 2 Kings 23:4-20. Several verses later, 2 Kings 23:24 briefly reports Josiah's removal of the abominations from Judah and Jerusalem, including mediums, wizards, teraphim, and idols (גלולים), motivated by the book found in the temple. The parallel of the verse can be found in 2 Chronicles 34:33, which briefly recapitulates Josiah's removal of the abominations motivated by the book found in the temple (vv. 30-32). The Chronicles passage (esp. v. 33), however, omits the details in its Vorlage, including גלולים, and only designates them generally as all the abominations. (כל התועבות)

of Northern Israel in 2 Kgs 17:12 that contains גלולים is entirely omitted in Chronicles. The term appears in the account of Manasseh's transgressions (2 Kgs 21:11), yet the entire section of the judgement speech (vv. 11-15) is replaced by the account of his rehabilitation through punishment, repentance, and religious restoration (2 $\mathrm{Chr}$ 33:11-17).

52 See Klein, 2 Chronicles, 213.

53 Japhet, Chronicles, 706.

54 The Chronicler also removes "like his father David" (כדוד אביו, 1 Kgs 15:11b), because David is an incomparable cultic founder for the Chronicler. The mention of male cult prostitutes (כקדשוים, v. 12a) is removed in Chronicles in an intentional silence about them. See Japhet, Chronicles, 706. 
In these three passages, the avoidance of גלולים is hardly accidental but appears to be purposeful. Japhet also notices the lack of גלולים in Chronicles and argues that the Chronicler is probably following the spirit of the Deuteronomic precept in Deuteronomy 7:5, which lacks the term. ${ }^{55}$ Yet, as discussed above, גלולים also appears in Deuteronomy 29:16 and other passages in Kings. The intentional absence of the term is also perceivable by considering that Chronicles readily employs other terms for idolatry. For example, another typically Ezekielian term for idolatry (or idol), תועבה, is used without reluctance (2 Chr 28:3; 33:2; 34:33;

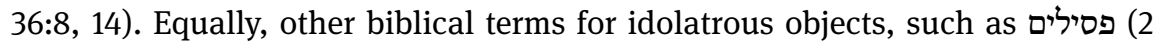
Chr 33:19, 22, etc.), מפלצת (2 Chr 15:16), מצבה (2 Chr 14:2; 31:1), 28:2; 34:3), and אשרה (2 Chr 14:3; 15:16, etc), are employed without avoidance. It is only גלולים

It seems that the absence of גלולים was a deliberate and careful choice by the Chronicler related to the Levites' idolatry in Ezekiel 44. Whether the accusation was true or false, any account of idolatry, especially of גלולים, in the monarchic period may have been reminiscent of the Levites's idolatry to those who were acquainted with the Ezekiel text. The Chronicler probably endeavored to prevent this possibility through a strategic ignorance of the term in order to neutralize the possible influence of Zadokite accusations for the audiences/readers of Chronicles.

\subsection{Jeroboam's Golden Calves}

The case to be examined in detail is the account of Jeroboam's golden calves (1 Kgs 12), which is denounced by the Deuteronomist as the primary cause of the generations of idol worship in Israel and its subsequent destruction (e. g., 2 Kgs 17:22-23). Including Jeroboam's two calves, as discussed above, the idols that Israel worshiped are expressed with the term גלולים (2 Kgs 17:12, 16). 1 Kings 12:26-33 reports three grave sins of Jeroboam: (1) establishing the cult of the golden calves in Dan and Bethel and building houses for the high places (vv. 26-31a); (2) appointing non-Levite priests for the high places and the Bethel sanctuary (vv. 31b, 32b); (3) setting a new date for the Autumnal festival (v. 32a). Scholars argue for an editorial nature of the main part of the passage, pointing out that v. 30 is already the conclusion of the account:

ויהי הדבר הזה לחטאת וילכו העם לפני האחד עד דן And this thing became a sin, for the people went to worship before the one as far as Dan.

55 Japhet, Chronicles. 
The following vv. 31-33, the accounts of the non-Levite priests and the new festival date, are consequently assigned to a late addition. ${ }^{56}$ Juha Pakkala further distinguishes between layers in this passage. ${ }^{57}$ He argues that the original layer ends with vv. 31a and 33b, and that the intervening passage, vv. 31b-33a, is a series of later expansions. The major part of the expansion is, according to Pakkala, the passage about appointing non-Levite priests: "and appointed priests from among all the people, who were not Levites" (v. 31b). Defining this redactional phase as "Levitical redaction", Pakkala claims that it intended to undermine the status of the Northern cultic sites by emphasizing the non-Levite priesthood there. ${ }^{58}$ This is, however, only one side of the coin. As Mordechai Cogan has rightly observed, none of the Mosaic laws would legitimize idolatrous cultic sites by the presence of Levitical priests. ${ }^{59}$ If we assume, with Pakkala, that a Levitical scribe was responsible for this addition, the purpose should be to deny the Levites's involvement in Jeroboam's idol worship.

Nevertheless, as a result of this redaction, the present form of Jeroboam's account in Kings gives the impression that there were Levites in the Northern Kingdom and that Jeroboam should have appointed priests from among the Levites for his sanctuaries (vv. 31-32). Further, the passage in the present form implies that the Levites in the North might have served at the royal sanctuaries and local high places if the circumstance allowed. This, however, would not be what the "Levite redaction" intended.

The Chronicler's parallel account (2 Chr 11:13-17) mentions Jeroboam's transgressions only briefly, in a single verse (v. 15, cf. 2 Chr 13:9); in the same passage, the Chronicler focuses on the immigration of the Northern priests, Levites, and pious laity. The major difference from Kings is that all of the priests and Levites had left Jeroboam and the Northern Kingdom and came to Jerusalem to worship Yhwh. The Levites were thus completely disconnected from the idolatrous Northern cult. This "complete disconnection" between the Levites and the Northern cult precludes all possible "misunderstandings" about the Levites by the audi-

56 For example, see Alfred Jepsen, Die Quellen des Königsbuches, 2nd ed. (Halle: Niemeyer, 1956), 6; Volkmar Fritz, Das Erste Buch der Könige, ZBKAT 10.1 (Zürich: Theologischer Verlag, 1996), 127-128; Christoph Levin, “Die Frömmigkeit der Könige von Israel und Juda,” in Verheißung und Rechtfertigung: Gesammelte Studien zum Alten Testament II, BZAW 431 (Berlin: Walter de Gruyter, 2013) 144-77, here 138-39.

57 Juha Pakkala, “Jeroboam Without Bulls,” ZAW 120 (2008): 501-25, here 509-11.

58 Pakkala, “Jeroboam”, 522.

59 Mordechai Cogan, 1 Kings: A New Translation with Introduction and Commentary, AB 10 (New York: Doubleday, 2001), 360. 
ences/readers of Kings. The complete disconnection is precisely achieved through details of the Chroniclers' account.

Firstly, vv. 13-14a justify the presence of the Levites in the Northern Kingdom by referring to the Levitical cities distributed to the Levites (Josh 21; 1 Chr 6:39-66 [ET 6:54-81]; 13:2). ${ }^{60}$ It is the Chronicler's view that the Levites (and priests) already settled in towns distributed to them in both the North and the South before the monarchic period (1 $\mathrm{Chr} 13: 2)$ and in turn served the Temple in Jerusalem (1 Chr 24:19, 31). They were thus present in the North not because of service in local sanctuaries, but because Joshua had allocated towns and pastureland to them. They had not inhabited the Northern towns since the very beginning of the Northern Kingdom, for the Chronicler, so that they were always pious to Yhwh and the temple of Jerusalem and never had contacts with Northern idolatry. Notably, only the Levites, and not the priests, are mentioned in describing their royalty and pious deeds, such as abandoning their lands and holdings (v. 14a), ${ }^{61}$ in contrast to most of the other verses mentioning both the priests and the Levites together in the same context (2 Chr 11:13; 13:9-11). ${ }^{62}$ As a consequence, the Levites' roles appear more dominant in the pious deeds of leading the Northern laity to Jerusalem and strengthening Rehoboam's reign. ${ }^{63}$

The following half-verse (v. 14b) further eliminates any possible connection between the Levites and the Northern cult. Dillard rightly observes that the Chronicler "has also made explicit Jeroboam's rejection of the Levitical priests: rather than simply reporting his indiscriminate hiring practices as done in 1 Kings 12:32; 13:33." ${ }^{64}$ The Chronicler explicitly indicates that Jeroboam rejected the Levites serving as "priests of Yhwh," rather than serving as priests of his high places (cf. 1 Kgs 12:31; 13:33-34). This slight revision clarifies that the Levites served and expected to serve Yhwh alone and effectively denies the possible implication of those Kings passages concerning Levites and the Northern high places. The

60 The terms מגרש and (v. 14a) also occur together in Josh 21 (vv. 12, 41). See further James T. Sparks, The Chronicler's Genealogies: Towards an Understanding of 1 Chronicles 1-9, Academia Biblica 28 (Atlanta: Society of Biblical Literature, 2008), 150-52.

61 Williamson has argued that v. 41a is late addition. See Hugh G. M. Williamson, 1 and 2 Chronicles, NCB (Grand Rapids, MI: Eerdmans, 1982), 243. Cf. Klein's criticism on this view (2 Chronicles, 174).

62 Cf. Japhet, Chronicles, 669. Japhet argues that the Levites here include the priests, but this is not a wording typical of the Chronicler, who also designates the priests as הלוים.

63 For example, ואחריהם (v. 16) literarily indicates only the Levites. In addition, the grammatical subject of ויאמצו ויחז is only the Levites and the northern people led by them, and not the priests.

64 Dillard, 2 Chronicles, 97. 
severance between the Levites and the Northern cult is perpetuated in Chronicles by the addition of "ובניו" (and his sons, v. 14b), which is missing in the Kings account: Not only Jeroboam but also his successors rejected the Levites, ${ }^{65}$ thus permanently separating the Levites from the Northern cult. This may have been an effective additional explication to prevent overinterpretation of their service to Rehoboam for only three years (v. 17), which could have been interpreted as the Levites' return to the Northern Kingdom.

Further, in the brief description of Jeroboam's idolatry (v. 15), the Chronicler adds goat-demons (שעירים) in addition to calves and high places. As commentators agree, the goat-demons refer to Leviticus 17:7, which forbids the sacrifices offered in the open fields and outside the legitimate sanctuary (the Tent of Meeting). ${ }^{66}$ With this addition, the Chronicler projects the dichotomy between the legitimate sanctuary and the others expressed in Leviticus 17:7 to the Jerusalem temple and the Northern cultic sites. This implied dichotomy further enhances the ideological and theological distance between the Levites and Northern idolatry.

The present form of the Jeroboam account in 1 Kings 12-13 distinguishes between his transgression of building idolatrous cultic sites (1 Kgs 12:31a, 32a;13:13) and his appointment of non-Levitical priests there (1 Kgs 12:31b; 13:33). The distinction was, as shown above, caused by the Levitical additions. In Chronicles, however, the legitimate place and personnel are not separate matters but are intrinsically combined into one (also 2 Chr 13:9-11). ${ }^{67}$ Again, the Levites cannot be related to cultic sites other than the temple of Jerusalem in the Chronicler's theological scheme.

\subsection{Josianic Reform}

The Chronicler takes pains to deny all possible connections between the Levites and idol worship in Judah as well. Among many examples, the Chronicler's account of the Josianic reform deserves a close examination, particularly because its Vorlage (2 Kgs 23) is thought to explain the origin of the priestly hierarchy in

65 Here, "his sons" should be understood as his successors. See also Japhet, Chronicles, 669. Cf. Dillard, Chronicles, 97.

66 See Japhet, Chronicles, 668; Dillard, Chronicles, 97; Klein, 2 Chronicles, 175. For Lev 17:7, see Jacob Milgrom, Leviticus 1-16: A New Translation with Introduction and Commentary, AB 3 (New York: London [etc.]: Doubleday, 1991), 1462.

67 See Japhet, Chronicles, 669. 
Jerusalem. ${ }^{68}$ According to the majority view of 2 Kings 23:8-9, Josiah gathered the deposed local priests in Judah in Jerusalem, but they had no priestly right to participate in the sacrificial service in Jerusalem (cf. Deut 18:7).$^{69}$ The assembled priests were also Yahwistic priests distinguished from the idolatrous priests, called כמרים (2 Kgs 23:5). ${ }^{70}$ The passage thus reports that the Josianic reform caused a stratification between the two Yahwistic priestly groups in the Jerusalem temple, between the Jerusalemite priests serving at the altar of Yhwh (v. 9a) and those from the local sanctuaries without access to it (v. 9b). Although the account never mentions a Levitical identity for either group, the described situation looks quite similar to the Zadokite passages in Ezekiel. As shown above, a distinction appears between the priests serving at the altar and the priests serving in the house (Ezek 40:45-46a); the Zadokite passages develop the distinction and identify the two groups of priests as the Levitical Zadokite priests and the Levites, respectively (e.g., Ezek 44:10-15). The similarity becomes closer if one regards the

68 The Kings account of Josiah's purge of idols is, like the whole of Kings, thought to have been subjected to multiple stages of expansion from the time of Josiah to the postexilic period. Therefore, Steven McKenzie, for example, argues that the Chronicler had only the Josianic version of Kings (Dtr ${ }^{1}$. Boyd Barrick uses this conception for explaining differences between Josiah's accounts in Kings and Chronicles. See Steven L. McKenzie, The Chronicler's Use of the Deuteronomistic History, HSM 33 (Atlanta: Scholars Press, 1985); W. Boyd Barrick, The King and the Cemeteries: Toward a New Understanding of Josiah's Reform, VTSup 88 (Leiden: Brill, 2002), 61-63. However, most redaction-critical studies of the Kings account of Josiah puts the gathering of the priests to Jerusalem (2 Kgs 23:8a) in the original account. Even Christoph Levin, who reconstructs a very brief original account, regards the passage as original; see Christoph Levin, "Joschija im deuteronomistischen Geschichtswerk," ZAW 96 (1984): 351-71; reprinted in Christoph Levin, Fortschreibungen: Gesammelte Studien zum Alten Testament, BZAW 316 (Berlin: Walter de Gruyter, 2003), 198-216.

69 This has been the majority view since Wellhausen. Against the majority view, some alternative interpretations have been suggested. See, e. g., Roland de Vaux, Ancient Israel: Its Life and Instructions, trans. John McHugh (Grand Rapids, MI: Eerdmans, 1961), 363; Ernest Nicholson, "Josiah and the Priests of the High Places (II Reg 23,8a.9)," ZAW 119 (2007): 499-513; idem, "Once Again Josiah and the Priests of the High Places (II Reg 23,8a.9),” ZAW 124 (2012): 356-368; Mark Leuchter, “'The Levite in Your Gates': The Deuteronomic Redefinition of Levitical Authority,” JBL 126 (2007): 417-36; Barrick, Cemeteries, 189-93.

70 See, e.g., John Gray, I \& II Kings: A Commentary, 3rd ed., OTL (London, SCM Press, 1977), 732-733; Gwilym H. Jones, 1 and 2 Kings, NCBC (Grand Rapids, MI: Eerdmans, 1984), 618; Jimmy J. M. Roberts, Nahum, Habakkuk, and Zephaniah: A Commentary, OTL (Louisville, KY: Westminster/John Knox Press, 1991), 172; Gary N. Knoppers, Two Nations Under God: The Deuteronomistic History of Solomon and the Dual Monarchies, 2 vols., HSM 52 (Atlanta: Scholars Press, 1993), 188; Phyllis A. Bird, "The End of the Male Cult Prostitute: A Literary-Historical and Sociological Analysis of Hebrew qādēš-qédēšîm,” in Congress Volume, Cambridge 1995, ed. John A. Emerton, VTSup 66 (Leiden/ New York/Köln; Brill, 1997), 65 n 91. 
sons of Zadok (בני צדוק) as the Jerusalemite priests, following the majority view. The situation reflected in Deuteronomy 18:6-7 is also similar in its recognition of two groups of Levites or Levitical priests; those officiating at the chosen place and those coming from other parts of the land. The similarities among the three passages led earlier generations of scholars to believe that all of them were describing one historical event, the Josianic reform.

I am not arguing here that the Josianic reform was the definite historical origin of this distinction, nor would I say that Ezekiel's account of the Levites' idol service indicates the time of Josiah. I am simply suggesting the possibility that, regardless of the historical reality, the similarity of the situations described in these passages caused them to overlap among the literate elites of Yehud. In other words, the Chronicler or his primary audiences/readers may have naturally made a connection between the clerical stratification in Ezekiel 44 and the similar distinction between Jerusalemite and local priests in 2 Kings 23 (Deut 18:6-7). Were this the case, it would not be without benefit to examine whether the Chronicler is responding to the accusation of the Levites in Ezekiel 44 in his account of Josianic reform.

The Chronicler significantly shortens the Vorlage of 2 Kings 23:4-21 in describing Josiah's purging of idolatry (2 Chr 34:3-7), while he extends other accounts such as the observance of Passover and Josiah's death at the hands of Pharaoh Neco (2 Chr 35). ${ }^{71}$ Regarding the idol purge, Josiah is a major hero in the Deuteronomistic history of Israel; he is one of the many Judean kings who enacted religious reforms in Chronicles (Asa, Jehoshaphat, Hezekiah, Manasseh, etc.). ${ }^{72}$ Josiah continued and completed the reform that his grandfather Manasseh started (cf. 2 Chr 33:15-17), rather than initiating it by himself. Nevertheless, the Chronicler's account of Josiah's reform makes an interesting modification in terms of the fate of the local priests that has not received much scholarly attention thus far. ${ }^{73}$

71 See Japhet, Chronicles, 1018; Louis C. Jonker, Reflections of King Josiah in Chronicles: Late Stages of the Josiah Reception in II Chr. 34f., Textpragmatische Studien Zur Literatur- und Kulturgeschichte Der Hebräischen Bibel 2 (Gütersloh: Gütersloher Verlagshaus, 2003), 31-33.

72 See further Jonker, King Josiah, 32 n 17; Japhet, Chronicles, 1020. Cf. Dillard, 2 Chronicles, 278. 73 There have been some recent studies on the Chronicler's account of the Josianic reform; see, e. g., Ehud Ben Zvi, “Observations on Josiah's Account in Chronicles and Implications for Reconstructing the Worldview of the Chronicler," in Essays on Ancient Israel in Its Near Eastern Context: A Tribute to Nadav Na'aman, ed. Yairah Amit et al. (Winona Lake, IN: Eisenbrauns, 2006), 89-106; idem, "Revisiting 'Boiling in Fire' in 2 Chron. 35.13 and Related Passover Questions: Text, Exegetical Needs, Concerns, and General Implications," in Biblical Interpretation in Judaism and Christianity, eds. Isaac Kalimi and Peter J. Haas, Library of Hebrew Bible/Old Testament Studies 439 (London: T\&T Clark, 2006), 238-250; Jonker, King Josiah; Christine Mitchell, “The Ironic Death of Josiah in 2 Chronicles," CBQ 68 (2006): 421-435; Mordechai Cogan, “The Chronicler's Use of 
Two points of the modification are especially noteworthy: First, the Chronicler combines the different motifs of defiling in 2 Kings 23 into one action. According to Kings, the purge of the high places was implemented with three different measures: Josiah defiles (טמא) the high places in Judah and Solomon's high place in Jerusalem and gathers the priests to Jerusalem (2 Kgs 23:8, 13); at Bethel, he destroys and crushs high places to dust and defiles the altar by burning human bones on it (vv. 15-16); he does the same to the high places in the towns of Samaria but also sacrifices (ויזבח) the priests on their altars (vv. 19-20). Josiah's purges become more severe as he moves northward. The priests at the high places in Judah survive and are called up to Jerusalem, while the priests at the Samarian towns are slaughtered.

Chronicles, however, eliminates the contrasting treatments of the Southern and Northern local priests. The Chronicler combined the burning of human bones on the altars at the Samarian towns with the killing of the local priests, saying that Josiah "burned bones of the priests on their altars" (2 Chr 34:5). This purge is made at the high places in Judah and Jerusalem (v. 3). The fate of these local priests is not explicitly mentioned, yet their bones burning on their altars presupposes that the local priests died already ${ }^{74}$ In other words, the Chronicler is trying to suggest the death of the local priests in Judah and Jerusalem. Further treatment of the priests in Kings, such as gathering or slaughtering them, is thus no more relevant to the Chronicler. Most importantly, no local priests came to the temple of Jerusalem, and, consequently, the separation between altar priests and non-altar priests never occurred.

Chronology as Illuminated by Neo-Assyrian Royal Inscriptions," in Empirical Models for Biblical Criticism, ed. Jeffrey H. Tigay (Philadelphia: University of Pennsylvania Press, 1985), 197-210; Christopher T. Begg, “The Death of Josiah in Chronicles: Another View,” VT 37 (1987): 1-8; Zipora Talshir, "The Three Deaths of Josiah and the Strata of Biblical Historiography (2 Kings xxiii 29-30, 2 Chronicles xxxv 20-25, 1 Esdras i 23-31)," VT 46 (1996): 213-36; Hugh G. M. Williamson, “The Death of Josiah and the Continuing Development of the Deuteronomic History," VT 32 (1982): 242-48; idem, "Reliving the Death of Josiah: A Reply to C. T. Begg," VT 37 (1987): 9-15; Michael A. Fishbane, Biblical Interpretation in Ancient Israel (Oxford: Clarendon, 1985), 137-43; Kenneth A. Ristau, "Reading and Rereading Josiah: The Chronicler's Representation of Josiah for the Postexilic Community," in Community Identity in Judean Historiography: Biblical and Comparative Perspectives, eds. Gary N. Knoppers and Kenneth A. Ristau (Winona Lake, IN: Eisenbrauns, 2009): 219-248. These works, with an exception of Barrick (The King and the Cemeteries), mostly focus on the Chronicler's extended accounts of Passover and/or Josiah's death.

74 Dillard interprets the passage as implying that Josiah executed the priests of Baal (2 Chronicles, 278), but the "bones" motif presupposes a certain length of time for body decomposition and is used as such in 2 Kings 23:16, 20. Especially in 2 Kings 23:20, Josiah's burning of bones and slaughtering of the priests are described as two separate actions. See also the criticism of Dillard in Barrick, Cemeteries, 23 n 20. 
This modification seems to be deliberate, considering that it betrays even the Chronicler's own historical reconstruction of the Judean high places. Worship in high places is not attacked in Chronicles as harshly as in Kings. Especially after Manasseh's purging of idols, the Chronicler adds that the people of Judah continued to sacrifice at the high places, but only to Yhwh (2 Chr 33:17). Japhet maintains that this is "the clearest biblical expression of the distinction between two kinds of high places: for idolatry and for the worship of the Lord."75 Josiah's reform started only ten years after Manasseh's death in Chronicles, ${ }^{76}$ which is not a long enough time for the natural demise of all priests of the high places. For the Chronicler, therefore, there must have been priests who sacrificed to Yhwh at the Judean high places in Josiah's time. ${ }^{77}$ Several tricky questions may then arise here: Who were these priests for the Chronicler? Were they Levitical? David once appointed Zadok as the priest of the high place of Gibeon (1 Chr 16:39); did Manasseh appoint "legitimate" priests of Yhwh at the high places he built? Furthermore, what happened to those priests of Yhwh after the Josianic reform? The Chronicler is totally silent about these issues. The high-place priests are simply regarded as already dead, and only their bones are humiliated. In this way, the Chronicler evaded these tricky questions by mentioning them as if they did not exist at the time of Josianic reform.

The Chronicler's lack of consistency with his own historical scheme implies that another strong factor influenced this process. This was probably the Chronicler's concern with and response to the notion of a hierarchy within the priestly circle mentioned in 2 Kings 23. The Chronicler's revision eliminates this issue and successfully precludes the possible connection made by Kings between the second-tier Levites in Jerusalem and the former priests of the Judean local sanctuaries. The Chronicler implicitly, but strongly, argued for the Levites' freedom from any accusation of a historical connection with idolatrous worship not only in the Northern Kingdom, but also in Judah. ${ }^{78}$

75 Japhet, Chronicles, 1011.

76 Amon reigned only two years (2 Chr 33:21), and Josiah started purging the idols during the eighth year of his reign in Chronicles (2 Chr 34:3) rather than eighteenth year (2 Kgs 22:3).

77 Barrick similarly argues that "in terms of narrative continuity, the 'bamoth' in question must be those which Manasseh rebuilt (2 Chr 33:3a) and at which 'the people continued to sacrifice, only to Yahweh their god' (2 Chr 33:17); this passing mention is the Chronicler's equivalent of 2 Kings 23:8a (where the priests are presumed to be Yahwistic [cf. v. 9])"; Barrick, Cemeteries, 20. 78 This interpretation also explains the omission of the slaughter of the Northern priests in $2 \mathrm{Kgs}$ 23:20. The Chronicler does not mention the priests in the Northern towns, presumably because the Northern priests are not within his realm of concern. Cf. Barrick, Cemeteries, 61, who argues that the absence of a report about the priests of the Northern towns was because of his Vorlage, which was an unaugmented version of Kings. 
In summary: The Chronicler neither explicitly mentions nor quotes Ezekiel, yet there are some clues for his knowledge of the prophetic book. Further, the profound (mutual) influence of Ezekiel in the composition of the Pentateuch can serve as circumstantial evidence for the acceptance of the former in the community of literate elites around the temple of Jerusalem to which the Chronicler belonged. Given the Chronicler's knowledge of the Zadokite accusation of idolatry against the Levites, the revision of the accounts of Jeroboam's golden calves and Josiah's purge against Judean idolatry can be understood in terms of the Chronicler's implicit reaction thereto. The two revised accounts preclude any possible connection between the Levites and idolatry both in the Northern Kingdom and in Judah. Further, the term גלולים, possibly reminiscent of the Zadokite accusation, is deliberately avoided throughout Chronicles. This is a subtle and careful way of scribal reaction that is intentional, consistent, and polemical, while simultaneously implicit, indirect, and hidden. In order to sharpen the understanding of the nature of this scribal work, it would be helpful to reinterpret the passages handled above within a theoretical framework of social theories in a heuristic manner.

\section{Some Sociological Observations}

\subsection{Zadokites' Symbolic Capital}

We have observed so far that the Zadokite priestly circle justified the degradation of the Levites through the accusation of idol worship especially in Ezekiel 44. As discussed above, the Levitical scribal works deliberately deny the Levites' possible connection to idol worship. The conflicting Zadokite and Levitical scribal activity may be more systematically understood within the theoretical frame of French sociologist Pierre Bourdieu. His studies focus on the division of social classes and how higher or more dominant classes justify and perpetuate class distinction. Already in early twentieth century, Italian sociologist Antonio Gramsci revealed that the dominant class acquires hegemony over a society, not only through economic power but also by manipulating cultural and academic institutions. ${ }^{79}$ In an agreement of Gramsci's theory, Bourdieu delves into smaller scale strategy of

79 For the application of Gramsci's hegenomy theory to the Zadokite and Levite scribal conflicts, see Jaeyoung Jeon, “The Zadokite and Levite Scribal Conflicts and Hegemonic Struggles," in Scripture as Social Discourse: Social-Scientific Perspectives on Early Jewish and Christian Writings, eds. Todd Klutz, Casey Strine, and Jessica M. Keady (New York: T \& T Clark, 2018), 97-110. 
the bourgeoise to perpetuate class divisions. ${ }^{80} \mathrm{He}$ argued that "capital" is not only limited to economic assets but also includes invisible assets on cultural and social levels. For Bourdieu, the dominant class is also distinguished from the lower classes by its access to and possession of social capital, such as social relationships as well as cultural capital such as the embodied habitus of the class members, the objectified state like pictures, texts, and academic qualifications. The possession of economic, social, and cultural capital by the dominant class is justified by "symbolic capital" that is represented by values such as honor, authority, and respect. Bourdieu claimed that symbolic capital exercises its power in a specific historical and social context that he defines as a "field."

The Zadokite redaction in Ezekiel can be understood as an attempt to create symbolic capital to justify their dominance in the temple and the community. The Zadokites' exclusive loyalty to Yhwh and their divine selection described in Ezekiel 44 should have been very powerful symbolic capital, especially in the social field of the temple. It shapes in its audiences/readers an honorable memory of the Zadokites, which could sufficiently justify their exclusive priestly prerogatives.

This symbolic power, according to Bourdieu, is exercised violently against the lower classes, especially when it imposes meanings in regard to the dominance of the ruling class and the social structure made by them. ${ }^{81}$ Bourdieu coined the term "symbolic violence" for this phenomenon. The accusation against the Levites as the rationale for their degradation in Ezekiel 44 serves as a good example, with the value of loyalty to Yhwh violently exercising its symbolic power against the lower-class Levites. This value served as symbolic capital for the Zadokites on the one hand; on the other, the lack of such loyalty violently deprives the Levites of priesthood.

According to Bourdieu, "the boundaries between the social classes are crystalized through codification, which indicates formalization of the class boundary." 82 This is an objectified frontier of the classes transformed by the symbolic power standing behind it. ${ }^{83}$ The Zadokite redaction in Ezekiel 44 can hereby be understood as a codification of the boundary between the priests and the second-tier Levites.

80 Pierre Bourdieu, In Other Words: Essays Towards a Reflexive Sociology (Stanford: Stanford University Press, 1990); idem, Language and Symbolic Power (Cambridge, MA: Harvard University Press, 1991).

81 See also David Swartz, Culture and Power: The Sociology of Pierre Bourdieu (Chicago: University of Chicago Press, 2012), 82.

82 Bourdieu, In Other Words, 82.

83 See Bourdieu, Language and Symbolic Power, 236. 
The Levitical scribal works may be interpreted in a similar manner. As I have discussed elsewhere, the Levites seem to have expanded their power and influence at a certain point in time during the Persian period, probably by assuming different tasks in temple service. The manual workers, gatekeepers, and the singers, who were separated in Ezra-Nehemiah, united themselves as a tribe with an organized genealogy in Chronicles. ${ }^{84}$ Joachim Schaper coined a term "united Levites" for the Levites in this stage. ${ }^{85}$ The Levites came to possess scribal capabilities as well, as seen in Chronicles and the so-called Levitical Psalms. To be sure, the Levitical roles in Chronicles are ideological and should not be taken as a historical reality of the Second Temple. One may accept, however, that their ideological scribal activity reflects their ambitions projected within the book, in their desired system of temple service in particular. ${ }^{86}$ The existence of professional scribes presupposes a certain degree of economic capital, and the resultant texts become cultural capital for the group. Given that the Levites possessed a certain degree of both economic and cultural capital, they must have also sought symbolic capital for justification. The Chronicler's description of David's appointment of the Levites for various tasks as well as their consistent loyalty to Yhwh worship in Jerusalem could function as the Levites' symbolic capital justifying their desirable status. The Chronicler created symbolic capital for the Levites equivalent to that of the Zadokites. At the same time, the deliberate scribal efforts to deny any possible Levitical connection to idol worship can be understood as an effective way of resisting the symbolic violence of the Zadokite scribes.

\subsection{Active Remembering, Reshaping, and Forgetting}

The scribal debates between the priestly and Levitical circles may also effectively be understood in terms of active ways of shaping and forgetting social memory in a community. The Zadokite redactor's work in Ezekiel 44 formulated a social memory of pious Zadokites and idolatrous Levites in the community that accepted Ezekiel as an authoritative text. Its repeated reinforcement in the memories of the readers/audiences justified and strengthened the distinction between the two

84 See further, Jaeyoung Jeon, "The Zadokites in the Wilderness: The Rebellion of Korach (Num 16) and the Zadokite Redaction,” ZAW 127 (2015): 381-411, esp., 401-403.

85 Joachim Schaper, Priester und Leviten im Achamenidischen Juda: Studien zur Kult- und Sozialgeschichte Israels in Persischer Zeit, FAT I 31 (Tübingen: Mohr Siebeck, 2000), 230-40.

86 See for a further discussion, Jeon, "Hegemonic Struggle." 
clerical classes on the one hand, while honoring the priests and humiliating the Levites on the other.

For the Levites, the Zadokite accusation should have been forgotten rather than remembered. The Chronicler performed this task by reshaping major "sites of memory" (lieux de mémoire) of Israelite idolatry. ${ }^{87}$ Firstly, the Chronicler deliberately ignored the term גלולים despite its presence in the Vorlage, since this term could be a site of memory that was strongly connected to the Levitical idolatry in Ezekiel 44. Additionally, the Chronicler reshaped the narrative of Jeroboam's golden calves, which is the major site of memory for idolatry of the Northern Kingdom in the Deuteronomistic History. He explicitly described the Levites' piety in leaving the North and abandoning their possessions and, in this way, completely removed them from this "crime scene." Josiah's religious reform is the site of memory for the division between the altar priests and other temple priests/ personnel related to purging of illegitimate sanctuaries. This site likely overlapped with the memory site created by Ezekiel 44 among the reader/audience community. The Chronicler completely eliminated this memory site by reshaping the memory of Josiah's reform, according to which the priests of the high places were already dead and could not have come to Jerusalem.

The Chronicler's efforts to reshape memory were also an active way of collective forgetting the Zadokite accusation. According to Umberto Eco, an Italian literary critic and semiotician, one forgets not by a cancelation of memory but by confusion of memories caused by superimposition of different notions and terms; that is, not by producing absence but by multiplying presences. Therefore, an effective strategy for producing "oblivion”, according to Eco, is to superimpose different memories on the same issue. ${ }^{88}$ The Chronicler's revision of the monarchic history was an effective strategy in this manner. The Chronicler superimposed the alternative history of the pious and loyal Levites upon the Zadokite

87 I use the phrase "site of memory" in a broader sense employed by Ben Zvi, who defines it as "any constructed space, place, event, figure, text of the like - whether it exists 'materially' or only in the mind of members of a social group - whose presence in the relevant cultural milieu evokes or was meant to evoke core images or aspects of images of the past held by the particular social group who lives in that cultural milieu"; see Ehud Ben Zvi, "The Study of Forgetting and the Forgotten in Ancient Israelite Discourse/s: Observations and Test Cases," in Cultural Memory in Biblical Exegesis, eds. Trine Hasselbach, Pernille Carstens, and Niels P. Lemche, Perspectives on Hebrew Scriptures and its Contexts 17 (Piscataway, N.J.: Gorgias Press, 2012) 139-157: 141. See also Ehud Ben Zvi, “Chronicles and Social Memory,” Studia Theologica: Nordic Journal of Theology 71 (2017): 69-90.

88 Umberto Eco and Marilyn Migiel, “An Ars Oblivionalis? Forget It!” PMLA 103.3 (1988): 254-261: 259. See also Doron Mendels, Memory in Jewish, Pagan and Christian Societies of the Graeco-Roman World, Library of Second Temple Studies 48 (London; New York: T\&T Clark, 2004). 
version in Ezekiel 44, strategically confusing and destroying the relevant memory sites in the social memory of the community. In this way, the negative memory of the Levites is confused and forgotten. This is an effective way of forgetting, against the priestly attempt of active remembrance.

\section{Conclusion}

This essay has investigated the Zadokite redaction of Ezekiel 44 and the possible scribal reaction of the Chronicler in favor of the Levites. This investigation had yielded the following plausible scenario: The Zadokite scribe endeavored through the redactional work in Ezekiel to enhance their exclusive priestly rights through perpetuating the class distinction between them and the rest of the Levites. Once this text was accepted as an authoritative prophetic book, first by the priestly circle in Jerusalem and subsequently by the wider community, it attained position in the social memory of the community regardless of its historicity. The created memory of exclusive Zadokite loyalty to Yhwh provided them with symbolic capital justifying their monopoly of the priesthood in the socio-religious realm of the temple. The remembrance of the accusation of idolatry against the Levites inflicted symbolic violence against the Levites. Chronicles represents a resistance by the Levitical scribal circle against the symbolic violence of the priestly scribes and, at the same time, Levitical attempts to gain their own symbolic capital. Furthermore, the Chronicler endeavored to collectively forget the memory of the idolatrous Levites in Ezekiel 44 by reshaping and producing the memory of pious Levites during the monarchic period. This result makes it possible to see Chronicles not only as an ideological text promoting the status of the Levites, but also as a Levitical response to the priestly ideology and temple order. 